\title{
Therapeutic itineraries of Qom mothers in a peri-urban community of Formosa
}

\author{
Shalila de Bourmont, Student ${ }^{a}$, Sofía Olmedo, B.S. ${ }^{b}$, Penélope Rodríguez, Magister ${ }^{c}$ and \\ Claudia Valeggia, PhD. ${ }^{d}$
}

\begin{abstract}
Introduction. Indigenous peoples are undergoing profound lifestyle changes that affect their health and the way they manage their diseases. The objective of this study was to determine the therapeutic itineraries followed by Qom mothers whenever they perceive their children are sick. Population and methods. The study was done in the Namqom peri-urban community, in the province of Formosa, with a group of mothers with young children interviewed at their houses until achieving saturation. The study followed an exploratory, qualitative design based on a conceptual health belief model.

Results. The therapeutic itineraries selected by 16 Qom mothers included using home remedies, biblical/faith healing, healers, and visiting the provincial health center. In general, the itinerary depends on how the mother characterizes disease symptoms: natural (biological cause)or unnatural (sorcery-related). The different methods are not necessarily incompatible and, many times, are used as complementary. Both reliability on effectiveness and fear of consequences play an important role on treatment selection. These results are extremely helpful to improve the dialog between the community and the health center. It is necessary to promote an improved coordination among the different health care agents working in transitioning indigenous communities.

Conclusions. The results of this study described selected therapeutic itineraries and, as a consequence, evidenced the strong presence of pluralistic medical systems in this community. Keywords: indigenouspeoples' health, interculturality, faith healing, sorcery, demographic transition.
\end{abstract}

http: / / dx.doi.org/10.5546/ aap.2020.eng.240

Claudia Valeggia, PhD.: claudia.valeggia@yale.edu

Funding:

This study was partially funded by Yale University through a grant for independent studies awarded to SDB and by a National Science Foundation grant awarded to $\mathrm{CV}$ (NSF BCS-0952264).

Conflict of interest: None.

Received: 8-3-2019

Accepted: 12-26-2019

To cite: de Bourmont $S$, Olmedo S, Rodríguez $\mathrm{P}$ Valeggia C. Therapeutic itineraries of Qom mothers in a peri-urban community of Formosa. Arch Argent Pediatr 2020;118(4):240-244.

\section{INTRODUCTION}

Worldwide, regardless of living conditions, almost 400 million indigenous peoples have very low health standards. ${ }^{1,2}$ Such health care inequalities particularly affect indigenous women and children, whose infant mortality, malnutrition, and maternal mortality rates are higher than those of non-indigenous peers. ${ }^{3}$

Qom communities in Argentina are no exception. As Argentine citizens, they can access free medical services in public hospitals and health centers. ${ }^{4}$ Most Qom people live in the provinces of Chaco and Formosa, which have the worst health indicators at a national level. ${ }^{5}$ As they progress towards a more global lifestyle integrated into the Western market, indigenous mothers face different health systems that include both traditional and Western models.

A better understanding of the complex interaction among cultural, social, and structural variables affecting these decisions may help to optimize coordination through multiple approaches and reduce the burden of health-related inequalities affecting these indigenous peoples. The objective of this study was to determine the factors that influence Qom mothers' choices in relation to their children's health care.

\section{METHODS}

Study population: This study was done in Namqom, a Qom settlement with 3500 inhabitants located $11 \mathrm{~km}$ west of the city of Formosa, in the North of Argentina. Although their mother tongue was their main language, most people also spoke Spanish fluently. All Namqom families lived below the poverty line 
for Argentina and suffered discrimination and social injustice. ${ }^{6,7}$ People living in the neighborhood could easily access Western biomedical care at the health center and the city's hospital, which depended on the Ministry of Human Development of Formosa. Antenatal and postnatal care programs were offered at no cost at the neighborhood's health center and the city's hospital, which is located approximately $15 \mathrm{~km}$ from the Namqom community.

Study design: This was an exploratory, qualitative study based on a health belief model. ${ }^{8}$ Mothers for the sample were selected purposively. Participants were selected from an existing cohort of 150 mothers involved in a research project carried out by the Argentinean Chaco Area Reproductive Ecology Program. Based on this cohort, a subset was selected to include all the mothers with children younger than 5 years. The sample size was established based on theoretical saturation. ${ }^{9}$

Data collection: Interviews were done at the mothers' houses between May and August 2017. Interviews were semi-structured, open, and anonymous (see Annex).

Ethical considerations: A written consent form was obtained from all participants before the interview, and an oral consent was also requested. The protocol was approved by the Ethics Committee of Yale University under number 1501015214.

Analysis: Considering the analytical methodology used in previous studies on health and culture, a conceptual framework was implemented based on a list of preset codes. ${ }^{10-12} \mathrm{It}$ was completed successively using the grounded theory based on interview contents as new patterns and topics emerged. Throughout the process, the constant comparative method was used to ensure coding remained consistent and that the code structure evolved inductively. Coding was done with the NVivo software.

\section{RESULTS}

The sample was made up of 16 Qom mothers. Their average age was 32.8 years (range: $23-$ 45 years) and their younger children were aged 3 months to 4 years. They had an average parity of 4 children (range: 1-11). Fourteen mothers had finishedsome level of formal education, although only five had completed secondary education. Most participants were married or living with a partner.

\section{Factors that impacted on} therapeutic action selection

Two factors that impacted on the mother's selection were identified:

a) Perception of signs of a medical condition and determination of symptom severity

The mothers mentioned physical and emotional signs as indicators of disease in their children. For example, they referred to the aspect of their eyes as a clear disease indicator and described them as "bored" or "glazed" when their child was not feeling well. Although physical and emotional signs of disease were enough to prompt some mothers to seek medical care, the presence of specific symptoms seemed to be a requirement for them to become involved. Fever, diarrhea, and vomiting were mentioned among the most alarming symptoms because they were believed to cause lethargy, weakness, and weight loss.

\section{b) Understanding of disease etiology}

According to the collected data, diseases were classified into natural or unnatural. Natural causes were described as external causes directly related to the environment (cold, wind, humidity). These were similar to the biomedical understanding of disease etiology. Unnatural diseases were described as a more traditional folk or indigenous construction of disease. For example, a) "Vuelta del vasito de leche" (knocked glass of milk), characterized by vomiting, diarrhea, and fever. This condition referred to children allegedly having a glass of milk in their stomach that gets knocked over when they make sudden movements. b) "Ojeo" or "mal de ojo" (evil eye), which occurred when an evil person, a drunk man, or a woman who was having her period stared at someone. It developed during pregnancy or early childhood. According to the mothers, Western physicians used to diagnose "evil eye" as meningitis. c) "Empacho" (indigestion), which is characterized by dyspepsia, constipation or diarrhea; often, this was attributed to "heavy" (fatty) meals and was perceived as an undigested alimentary bolus stuck in the digestive tract. "Cuarurú" also presented with similar symptoms. It was thought to be caused by excessive chicken intake during pregnancy, but it only emerged after birth, during early childhood. 


\section{Relationship between disease prevention and etiology}

Prevention was almost totally absent in mothers' concept of health. Breastfeeding, which was an extensive community practice, was not mentioned as a preventive measure. In addition, the idea that disease was inevitable was a prevalent thought during interviews. Also, health check-ups or controls at the health center were not considered a form of disease prevention. Actually, some mothers referred that they did not take their children to the health center for a monthly check-up because "they were healthy." An adequate nutrition, hygiene, and health conditions were rarely mentioned as prevention strategies.

\section{Health system selection}

The following health systems were mentioned as a first course of action based on the response rate, in order:

1. Health center: This was the first course of action for most mothers. In spite of a lack of consensus on service quality and effectiveness, mothers chose this system because of familiarity with the service, accessibility, availability, and access to additional resources. The most common criticisms mentioned by mothers included: a) lack of care and respect from the medical staff, including long waiting hours; b) inconsistent service (no physicians on duty during the night or on weekends and holidays; poorly-stocked pharmacy, and insufficient drugs); c) inability to cure traditional diseases: mothers indicated that they felt frustrated when physicians did not recognize traditional diseases, such as the "knocked glass of milk".

2. Hospital: Opinions about the hospital were mostly favorable and included a high qualification and care from the staff, resource availability and accessibility, familiar and comfortable services. To get to the city's hospital, mothers used the family motorbike or took a public bus.

3. Home treatments: It was observed that pharmaceutical medications were used in the first instance, followed by home remedies and medicinal plants. Medications were bought without a prescription and, in general, they were believed to be more effective and appealing for children than those administered at the health center. Most medications were from Paraguay; the most common ones included acetaminophen (Medifar), Z-Cal ${ }^{\circledR}$ (Indufar), Lascamicetina ${ }^{\circledR}$ (Lasca), and Mentolina ${ }^{\circledR}$ ointment (Catedral). At the pharmacy, they bought pediatric aspirin, ibuprofen, QuraPLus ${ }^{\circledR}$, Pulmosan $^{\circledR}$, and various syrups. Home remedies were used after taking the children to the health center and as a complement for the biomedical treatment. Medicinal plants were mostly used for gastrointestinal conditions, such as stomachache, diarrhea, vomiting, and parasites. According to data, mothers had doubts in relation to these natural remedies due to the history of poisoning caused by medicinal plants.

4. Healers (traditional healers): A strong consistency was observed in mothers' reports about the management of the "knocked glass of milk." The treatment offered by healers consisted in a specialized realignment of the child's legs combined with herbal medicines and girdle use, all for three days.

"Healers" were perceived as health authorities who were respected. The connection between the healer and the patient was so strong that it was believed that diseases could be transferred. Mothers resorted to "healers" mostly for the management of the "knocked glass of milk." The person able to cure (and also cause) spells and curses in Qom is called pi'ogonaq. A pi'ogonaqis particularly feared, but they are rarely involved in pediatric diseases.

5. Faith healing: Faith healing consisted in praying sessions at church (Evangelical or Pentecostal), during which biblical passages were read. It was practiced by people who invoked the Holy Spirit and were endowed with its power. The most common types of faith healing included resuscitations, visions, and baptisms. Mothers said that diseases may be prevented by religious means.

\section{System interaction}

Mothers stated that there were no conflicts between the simultaneous or consecutive use of the biomedical system, faith healing, and the "healer." Actually, mothers often reported that "healers" told them to go to the health center after their treatment for the management of any residual fever that may result from the intensive traditional treatment.

However, faith (biblical) healing and traditional (shamanic) healing were considered inherently conflicting because mothers considered 
healers as healing agents endowed with the power of evil or diabolical spirits. In addition, the interaction between both systems may result in physical damage to the traditional "healer." An exception to this was when a "healer" was asked to treat the "knocked glass of milk" because of its etiology.

\section{Perceived effectiveness of health systems}

There was no direct relationship between the perceived capacity of a health system and its selection. Most people chose the biomedical health system when their children were severely ill and symptoms worsened. Only then, when a disease failed to be treated with Western medicine, it was considered to be caused by supernatural reasons and the traditional or faith healer was consulted. However, when dealing with the religious system, faith appeared to play a major role and most mothers trusted faith "healers" unequivocally.

In relation to "traditional healers," all interviewed mothers stated that they had experience with these healers and that their treatments had always been successful. In addition, when they explicitly described traditional treatments, it appeared that they fully accepted them without question. However, an almost universal acceptance of a "healer's" effectiveness did not translate into a universal service use. In fact, given that they believed that "healers" had the ability to cure and harm, fear of them by some mothers translated into a disconnection from their services. Therefore, interviews suggested that both fear and trust in effectiveness played an important role in the selection of a health strategy.

\section{DISCUSSION}

This study was the initial phase of an investigation about medical pluralism in these indigenous communities. It allowed to identify the main factors affecting the determination of therapeutic itineraries followed by Qom mothers. It was observed that both seeking treatment and its implementation and compliance were related to both the natural history of disease and sociocultural aspects, ${ }^{13}$ which were many times overlooked or directly rejected by the hegemonic health system.

Visiting the health center and self-medication were the first course of action for Qom mothers because they understood disease as having a natural etiology. This outcome, consistent with a previous study, ${ }^{14}$ showed certain receptiveness towards the biomedical approach, ${ }^{15}$ even if the community did not fully accept it. However, if biomedicine did not provide a fast symptom improvement, the origin of disease was construed as unnatural and the course of action shifted towards traditional healing. This study evidenced a consistent use of healers for the treatment of the "knocked glass of milk" or "indigestion," as observed in other Argentine populations. ${ }^{16-18}$

Qom mothers' knowledge in relation to the Western etiology of disease was limited and included a marked absence of the prevention concept. At this point, it was important to consider that indigenous communities had a comprehensive perspective of health where the spiritual aspect played a determining role. ${ }^{19}$

Like a previous investigation, ${ }^{14}$ this study evidenced that therapeutic itineraries in a pluralistic health system were not necessarily incompatible. People followed different itineraries not only for different health problems but also for the same one. ${ }^{20}$ Such "triangulation" concept may account for a potential intersection between Western medicine and the community.

The findings of this study helped to obtain preliminary information about the complex interactions that may take place in a pluralistic health system. The limitations of this study included its time framework and those inherent to a qualitative study. A deeper understanding of this problem may help to establish a better dialog between the biomedical system and the community, and thus travel the path towards health together, as peers.

\section{REFERENCES}

1. Stephens C, Porter J, Nettleton C, Willis R. Disappearing, displaced, and undervalued: a call to action for Indigenous health worldwide. Lancet. 2006; 367(9527):2019-28.

2. Valeggia C, Snodgrass JJ. Health of Indigenous Peoples. Annu Rev Anthropol. 2015; 44:117-35.

3. Inter-agency support group on Indigenous Peoples' issues. The Health of Indigenous peoples. In: Thematic Paper towards the preparation of the 2014 World Conference on Indigenous Peoples. 2014;1-14. [Accessed on: December $\left.27^{\text {th }}, 2019\right]$. Available at: https: / / www.un.org/en/ga/69/ meetings / indigenous / pdf / IASG \%20Thematic $\% 20$ Paper $\% 20-\%$ 20Health $\% 20-\% 20$ rev1.pdf.

4. Valeggia C, Ellison PT. Lactationalamenorrhoea in wellnourished Toba women of Formosa, Argentina. J Biosoc Sci. 2004; 36(5):573-95.

5. Ministerio de Salud.OPS.OMS. Indicadores Básicos. Argentina 2017. Buenos Aires. 2017;1-11. [Accessed on: December $27^{\text {th }}$, 2019]. Available at: http://www.deis.msal.gov.ar/wpcontent/ uploads / 2018/04/IndicadoresBasicos2017.pdf.

6. Delucchi M, Fontan M, Grichener S, Wassner M. Proyecto deSaneamiento Básico Integral: Barrio Namqom, Formosa. Formosa, Argentina: Convenio SDS-UNICEF, 1996. 
7. Alarcón-Muñoz AM, Vidal-Herrera AC. Dimensiones culturales en el proceso de atención primaria infantil: perspectivasdelasmadres. Salud Pública Méx. 2005;47(6):4406.

8. Rosenstock IM. Why people use health services. Milbank Mem Fund Q. 1966; 44(3):Suppl:94-127.

9. Russell HB. Research Methods in Anthropology: Qualitative and Quantitative Approaches. $4^{\text {th }}$ ed. Lanham: Altamira Press; 2006.

10. Dell'Arciprete A, Braunstein J, Touris C, Dinardi G, et al. Cultural barriers to effective communication between Indigenous communities and health care providers in Northern Argentina: an anthropological contribution to Chagas disease prevention and control. Int J Equity Health. 2014; 13:6.

11. Bonilla-Castro E, RodriguezSehk P. Más Allá del Dilema de los Métodos: La Investigación en Ciencias Sociales. $3^{\text {ra }}$ ed. Bogotá D.C: Universidad de los Andes, Grupo Editorial Norma; 2005.

12. Pope C, Ziebland S, Mays N. Qualitative research in health care. Analysing qualitative data. BMJ. 2000; 320(7227): 114-6.

13. Lago LM, Martins J, Schneider DG, Carvalho Barra DC, et al. Intinerarioterapeutico dos usuarios de una urgencia hospitalar. CiencSaudeColetiva. 2010; 15(Supl 1):1283-91.
14. Olmedo S, Berra S, Valeggia C. Perspectivas de madres Qom sobre la salud infantil. In: Abbona A, Roca I (eds.). Los pueblos indígenas de Ameria Latina Actas del CIPIAL. Santa Rosa: EdUNLPam; 2018.Págs.1-29.

15. Menéndez EL. Modelo médico hegemónico y atención primaria. Segundas Jornadas de Atención Primaria de la Salud. 30 de abril al 7 de mayo de 1988. Buenos Aires; 1988. Pages 451-64.

16. Martinez GJ. Pluralismo médico y etnomedicina entre los Tobas (Qom) del río Bermejito (Chaco, Argentina). Desafíos y aportes para una gestión intercultural de la salud en el impenetrable chaqueño. Rev Mus Antopol. 2011;4(1):195-210.

17. Arteaga F. Las medicinas tradicionales en la Pampa Argentina. Reflexiones sobre síntesis de praxis y conocimientos médicos, saberes populares y rituales católicos. AIBR. 2010; 5(3):397-429.

18. Idoyaga Molina A. Etiologías, síntomas y eficacia terapéutica. El proceso diagnóstico de la enfermedad en el Noroeste Argentino y Cuyo. Mitológicas. 2001; 16(1):943.

19. Stivanello MB. Aportes al debate de la Interculturalidad en salud. Margen. 2015; 76:1-8.

20. Menéndez EL. Modelos de atención de los padecimientos: de exclusiones teóricas y articulaciones prácticas. CiencSaúde Colectiva. 2003; 9(1)185-207. 


\section{ANNEX \\ Interview guide}

Interviews were semi-structured. Discussions were guided to ensure that participants talked about the following topics.

\section{INTRODUCTION:}

Good morning/afternoon. My name is xxx. We are conducting a study on the health of community children and what mothers do when their children are sick. I would be very grateful if you answered some questions. Your answers will be really helpful to better understand maternal needs when caring for a sick child. Anything you tell us will remain anonymous, i.e., your name will not be included in the study results.

\section{DEMOGRAPHIC SECTION}

1. How old are you?

2. How many children do you have? How old are they?

3. Did you go to school? What was the highest grade you completed?

4. Who shares your household? (To define family size and composition).

5. Are you married/living with a couple, single or a widow?

\section{GENERAL CONCEPTS ABOUT HEALTH AND DISEASE}

1. What does having a "good health" mean to you?

2. What does being sick mean to you?

3. How important is it for you to have a good health?

4. What do you do to keep your children healthy?

5. I have heard some people talk about "white people's diseases." Have you heard about it? What does it mean that a disease is "white"?

\section{KNOWLEDGE AND BELIEFS ABOUT PEDIATRIC DISEASES IN THE COMMUNITY}

1. To what extent do you think taking your child to the physician (healer) helps them to avoid sickness?

2. What are the most common diseases among children?

3. Why do children get sick with...?

\section{PERCEPTIONS ABOUT THE SEVERITY OF CHILDREN'S SYMPTOMS}

1. When do you usually start worrying or considering that what your child has is serious or severe?Why?

\section{COURSE OF ACTION TAKEN TO ASSESS SYMPTOM SEVERITY}

1. What is the first thing you do when your children get sick?

2. Who do you first talk to when your children get sick: family members or friends?

3. When do you use home remedies? What home remedies do you use? For which conditions?

4. When was the last time one of your children had a serious disease?

- Please tell me what you did.

- What prompted you to make that decision? Did anyone help you make that decision?

- What happened afterwards? 


\section{PREVIOUS EXPERIENCE WITH THE DIFFERENT HEALTH CARE SYSTEMS}

If the mother sought help, either at a health center or from a healer, the following questions were asked:

- How was your experience that time?

- What did the healer (physician) say and recommend?

- Did the medication/home remedy help your child? If the medications/home remedies were not helpful, what did you do afterwards?

- How did you feel about the way they treated you? What did you like and did not like about the experience?

Depending on where the mother took her child, she was asked about her experience with the other health care system (e.g., if the mother took her child to a health center, the question was about her latest experience with the healer).

- Why did you take your child to the healer (physician) that time?

- Please tell me more about this experience.

- What did the healer (physician) say and recommend?

- Did the medication/home remedy help your child? If the medications/home remedies were not helpful, what did you do afterwards?

- How did you feel about the way they treated you? What did you like and did not like about the experience? 